application would be highly important. Thus, he shows that while linseed oil is obtained in Holland, Germany and Middle Russia in the proportion of about 3 or $4 \mathrm{p}$. c. of the weight of the plants from which it is extracted, the yield from uncultivated plants in Norway varies from 4 to 5 , or 5 to 8 per cent. Again his experiments of the yield of the essential oil of lavender, have convinced him, that plants grown in Christiania or Throndhjem, when compared to those grown near Merton, which have hitherto been regarded as the first in the world, greatly excel the latter in aroma, and he considers that the cultivation of this plant could be carried on with undoubted success on the coast-lands of Norway.

While Dr. Schübeler has no hesitation in maintaining that light engenders aroma, as heat engenders sweetness, he has not been able to determine to what extent the vegetable alkaloids are affected by either. In connection with his own observations, he reports some curious particulars in regard to the action of continuous light in the polar regions, which he has obtained from intelligent residents, who had undertaken to conduct certain experiments under his direction. Thus it was found both at Alten in West Finmark, and at Stamsund in the Lafodens, that plants of Acacia lophantha never contracted their leaves during the two months, or longer, that the sun remained above the horizon. An experiment was made at Alten to shade one half of the crown of an acacia during the night, and the result was that in about twenty minutes' time, the protected leaves began to contract, and remained closed until the plant was ayain wholly exposed to the midnight-sun, when after a time the leaves began slowly to unfold. At Stamsund it was observed that whenever the acacias were placed on the north side of a house, which was partially screened by a neighbouring Fjæld, the leaflets turned upwards, without however wholly closing, and the same thing was noticed in rainy weather. The leaves of Mimosa pudica contracted in the lightest and clearest nights, and remained folded back for some hours.

Without entering further into the details of Dr. Schübeler's numerous experiments, we may summarise their results as follows :-

I. The grain of wheat, that has been grown in low lying lands, may be propagated with success on the high Fjælds, and will reach maturity earlier at such elevations, even although at a lower mean temperature. Such grain, after having been raised for several years at the highest elevation which admits of its cultivation, is found when transferred to its original locality to ripen earlier than the other crops which had not been moved. The same result is noticeable in grain that has been transported from a southern to a more northern locality, and vice versâ.

2. Seeds imported from a southern locality, when sown within the limits compatible with their cultivation, increase in size and weight, and these same seeds, when removed from a more northern locality to their original southern home, gradually diminish to their former dimensions. A similar change is observable in the leaves and blossoms of various kinds of trees and other plants. Further, it is found that plants raised from seed, ripened in a northern locality, are hardier, as well as larger than those grown in the south, and are better able to resist excessive cold.

3. The further north we go-within certain fixed limits-the more energetic is the development of the pigment in flowers, leaves and seeds. Similarly, the aroma, or flavour of various plants or fruits, is augmented in intensity the further north they are carried within the limits of their capacity for cultivation, conversely, the quantity of saccharine matter diminishes in proportion as the plant is carried further northward.

\section{MYTHOLOGIC PHILOSOPHY 1}

I. THE GENESIS OF PHILOSOPHY.-The wonders of the course of nature have ever challenged attention. In savagery, in barbarism, and in civilisation alike, the mind of man bas sought the explanation of things. The movements of the heavenly bodies, the change of seasons, the succession of night and day, the powers of the air, majestic mountains, ever-flowing rivers, perennial springs, the flight of birds, the gliding of serpents, the growth of trees, the blooming of flowers, the forms of storm-carved rocks, the mysteries of life and death, the institutions of society-many are the things to be explained.

The yearning to know is universal. How and why are ever. ${ }^{1}$ From Vice-Presidential Address of Prof. J. W. Powell, of Washington, Vice-President Section B, American Association for the Advancement of Science, Saratoga Meeting, August, 1879 . lasting interrogatories profoundly instinct in humanity. In the evolution of the human mind the instinct of cosmic interrogation follows hard upon the instinct of self-preservation.

In all the operations of nature man's weal and woe is involved. A cold wave sweeps from the north, rivers and lalies are frozen, forests are buried under snows, and the fierce winds almost congeal the life fluids of man himself, and man's sources of supply under the rocks of water. At another time the heavens are as brass, and the clouds come and go with mockery of unfulfilled promises of rain, the fierce midsummer sun pours its beams upon the sands, and scorching blasts heated in the furnace of the desert sear the vegetation, and the fruits, which in more congenial seasons are subsistence and luxury, shrivel before the eyes of famishing men. A river rages and destroys the adjacent valley with its flood. A mountain bursts forth with its rivers of hell, the land is buried, and the people are swept away. Lightning shivers a tree and rends a skull.

The silent, unseen powers of nature, too, are at work bringing pain or joy, health or sickness, life or death to mankind. In like manner, man's welfare is involved in all the institutions of society.

How and why are the questions asked about all these thingsquestions springing from the deepest instinct of self-preservation.

In all stages of savage, barbaric, and civilised inquiry, every que tion has found an answer, every how has had its thus, every why its because The sum of the answers to the questions raised by any people constitute its philosophy; hence all people have had philosophies consisting of their accepted explanation of things. Such a philosophy must necessarily result from the primary intincts developed in man in the early progress of his differentiation from the beast. This I postulate; if demonstration is necessary, demonstration is at hand.

Not only has every people a philosophy, but every stage of culture is characterised by its stage of philosophy. Philosophy has been unfolded with the evolution of the human understanding The history of philosophy is the history of human opinions from the earlier to the later days-from the lower to the higher culture. In the production of a philosophy phenomena must be discerned, phenomena must be discriminated, phenomena must be classified. Discernment, discrimination, and classification are the processes by which a philosophy is developed. In studying the philosphy of a people at any stage of culture, to understand what such a people entertain as the sum of their knowledge, it is necessary that we should understand what phe nomena they saw, heard, felt-discerned; what discriminations they made, and what resemblances they seized upon as a basis for the classification on which their explanations rested. A philosophy will be bigher in the scale, nearer the trutb, as the discernment is wider, the discriminations nicer, and the classifi. cation better.

The sense of the savage is dull compared with the sense of the civilised man. There is a myth current in civilisation to the effect that the barbarian has highly-developed perceptive faculties. It has no more foundation than the myth of the wisdom of the owl. A savage sees but few sights, hears but few sounds, tastes but few flavours, smells but few odours, his whole sensuous life is narrow and blunt, and his facts, that are made up of the combination of sensuous impressions, are few.

In comparison the civilised man has his vision extended away toward the infinitesimal and away toward the infinite; his perception of sound is multiplied to the comprehension of rapturous symphonies; his perception of taste is increased to the enjoyment of delicious viands; his perception of smell is developed to the appreciation of most exquisite perfumes; and the facts that are made up of his combination of sensuous impressions are multiplied beyond enumeration. The stages of discernment, from the lowest savage to the highest civilised man, constitnte a series, the end of which is far from the beginning.

If the discernment of the savage is little, his discrimination is less. All his sensuous perceptions are confused, but the confusion of confusion is that universal habit of savagery - the confusion of the objective with the subjective, so that the savage sees, hears, tastes, smells, feels the imaginings of his own mind. Subjectively determined sensucus processes are diseases in civilisation, but normal functional methotls in savagery.

The savage philosopher classifies by obvious resemblancesanalogic characters. The civilised philosopher classifies by essential affinities-homologic characteristics; and the progress of philosophy is marked by changes from analogic categories to homologic categories. 
2. Two Grand Stages of Philosophy. - There are two grand stages of philosophy-the mythologic and the scientific. In the first, all phenomena are explained by analogies derived from subjective human experiences; in the latter, phenomena are explained as orderly successions of events.

In sublime egotism man first interprets the cosmos as an extension of himself; he classifies the phenomena of the outer world by their analogies with subjective phenomena; his measure of distance is his own pace, his measure of time his own sleep, for he says, "It is a thousand paces to the great rock," or, "It is a thousand sleeps to the great feast." Noises are voices, powers are hands, movements are made afoot. By subjective examination discovering in himself will and design, and by inductive reason discovering will and design in his fellow-men and in animals, he exlends the induction to all the cosmos, and there discovers in all things will and design. All phenomena are supposed to be the acts of some one, and that some one having will and purpose.

In mythologic philosophy, the phenomena of the outer physical world are supposed to be the acts of living, willing, designing personages. The simple are compared with and explained by the complex. In scientific philosophy, phenomena are supposed to be children of antecedent phenomena, and so far as science goes with its explanation, they are thus interpreted. Man with the subjective phenomena gathered about him is studied from an objective point of view, and the phenomena of subjective life are relegated to the categories established in the classification of the phenomena of the outer world; thus the complex is studied by resolving it into its simple constituents. Some examples of the philosophic methods belonging to widely separated grades of culture may serve to make my statements clearer.

Wind.-The Ute philosopher discerns that men and animals breathe. He recognises vaguely the phenomena of the wind and discovers its resemblance to breath, and explains the winds by relegating them to the class of breathings.

He doclares that there is a monster beast in the north that breathes the winter winds, and another in the south, and another in the east, and another in the west. The facts relating to rinds are but partially discerned; the philosopher bas not yet discovered that there is an earth surrounding atmosphere. He fails also in making the proper discriminations.

His relegation of the winds to the class of breatnings is analogic, but not homologic. The basis of his philosophy is personality, and hence he has four wind gods.

The philosopher of the ancient Northland discovered that he could cool his brow with a fan, or kindle a flame, or sweep away the dust with the wafted air. The winds also cooled his brow, the winds also swept away the dust, and kindled the fire into a great conflagration, and when the wind blew he said, "Somebody is fanning the waters of the fiord," or "Somebody is fanning the evergreen forests," and he relegated the winds to the class of fannings, and he said, "The god Hraesvelger, clothed with eagle plumes, is spreading his wings for flight, and the wind rise from under them."

The early Greek philosopher discovered that air may be imprisoned in vessels or move in the ventilation of caves, and he recognised wind as something more than breatb, something more than fanning, something that can be gathered up and scattered abroad, and so when the winds blew he sald, "The sacks have been untied," or, "The caves have been opened."

The philosopher of civilisation has discovered that breath, the fan wafted breeze, the air confined in vessels, the air moving in ventilation, that these are all parts of the great body of air which surrounds the earth, all in motion, swung by the revolving earth, heated at the tropics, cooled at the poles, and thus turned into counter currents and again deflected by a thousand geographic features, so that the winds sweep across valleys, eddy among mountain crags, or waft the spray from the crested billows of the sea, all in obedience to cosmic laws.

The facts discerned are many, the discriminations made are nice, and the classifications based on true homologies, and we have the science of meteorology, which exhibits an orderly succession of events even in the fickle winds.

Sun and Moon.-The Ute philosopher declares the sun to be a living per-onage, and explains his passage across the heavens along an appointed way by giving an account of a fierce personal conflict between Ta-vi, the sun-god, and Ta-wats, one of the supreme gods of his mythology.

In that long ago, the time to which all mythology refers, the sun roamed the earth at will. When he came too near with his fierce heat the people were scorched, and when he hid away in his cave for a long time, too idle to come forth, the night was long and the earth cold. Once upon a time Ta-rats, the hare. god, was sitting with his family by the camp fire in the solemn woods anxiously waiting for the return of $\mathrm{Ta}$ vi, the wayward sun-god. Wearied with long watching the hare-god fell asleep, and the sun-god came so near that he scorched the naked shoulder of Ta-wats. Foreseeing the vengeance which would be thits provoked, he fled back to his cave beneath the earth. Ta-wats awoke in great anger, and speedily determined to go and fight the sun-god.

After a long journey of many adventures the hare-god came to the brink of the earth, and there watched long and patiently, till at last the sun.god coming out, he shot an arrow at his face, but the fierce heat consumed the arrow ere it had finished its intended course; then another arrow was sped, but that also was consumed, and another, and still another, till only one remained in his quiver, but this was the magical arrow that had never failed its mark. Ta-wats, holding it in his hand, lifted the barb to his eye, and baptised it in a divine tear; then the arrow was sped and struck the sun-god full in the face, and the sun was shivered into a thousand fragments, which fell to the earth, cansing a general conflagration.

Then Ta-wats, the hitre-god, fled before the destruction he bad wrought, and as he fled, the burning earth consumed his feet, consumed his legs, consumed his body, consumed his hands and his arms; all were consumed but the head alone, which bowled across valleys and over mountains, fleeing destruction from the burning earth, until at last, swollen with heat, the eyes of the god burst and the tears gushed forth in a flood, which spread over the earth and extinguished the fire.

The sun-god was now conquered, and he appeared before a council of the gods to await sentence. In that long council was established the days and the nights, the seasons and the years, with the length thereof, and the sun was condemned to travel across the firmament by the same trail day after day till the end of time.

In the same philosophy we learn that in that ancient time a council of the gods was held to consider the propriety of making
a moon, and at last the task was given to Whip-poor-will, a god of the night, and a frog yielded himself a willing sacrifice for this purpose, and the Whip-poor-will, by incantations and other magical means, transformed the frog into the new moon.

The truth of this origin of the moon is made evident to our very senses, for do we not see the frog riding the moon at night? And the moon is cold, because the frog from which it was made was cold.

The philosopher of Oraibi tells us that, when the people ascended by means of the magical tree which constituted the ladder from the lower world to this, they found the firmament-the ceiling of this world low down upon the earth-the floor of this world. Machito, one of their gods, raised the firmament on his shoulders to where it is now seen. Still the world was dark, as there was no sun, no moon, and no stars. So the people murmured because of the darkness and the cold. Machito said, "Bring me seven maidens," and they brought him seven maidens ; and he said, "Bring me seven baskets of cotton bolls," and they brought him seven baskets of cotton bolls; and he taught the seven maidens to weave a magical fabric from the cotton, and when they had finished it he held it aloft, and the breeze carried it away toward the firmament, and in the twinkling of an eye it was transformed into a beautiful full-orbed moon, and the same breeze caught the remnants of flocculent cotton which the maidens had scattered during their work, and carried them aloft, and they were transformed into bright stars. But still it was cold, and the people murmured again, and Machito said, "Bring me seven buffalo robes," and they brought him seven buffalo robes, and from the densely matted hair of the robes he wove another wonderful fabric, which the storm carried away into the sky, and it was transformed into the full-orbed sun.

Then Machito appointed times and seasons and ways for the heavenly bodies, and the gods of the firmament have obeged the injunctions of Machito from the day of their creation to the present.

The Norse philosopher tells us that Night and Day each has a horse and a car, and they drive successively one after the other around the world in twenty-four hours. Night rides first with her steed, named Dew-hair, and every morning as he ends his course he bedews the earth with foam from his bit. The steed 
driven by Day is Shining-hair. All the sky and earth glisten with the light of his name. Jarnved, the great iron-wood forest lying to the east of Midgard, is the abode of a race of witches. One monster witch is the mother of many sons in the form of wolves, two of which are Skol and Hate. Skol is the wolf that would devour the maiden, Sun, and she daily fies from the maw of the terrible beast, and the moon-man flies from the wolf Hate.

The philosopher of Samos tells us that the earth is surrounded by hollow crystalline spheres set one within another, and all revolving at different rates from east to west about the earth, and that the sun is set in one of these spheres, and the moon in another.

The philosopher of civilisation tells us that the sun is an incande cent globe, one of the millions afloat in space. About this globe the planets revolve, and the sun and planets and moons were formed from nebulous matter by the gradual segregration of their particles, controlled by the laws of gravity, motion, and affinity. The sun, travelling by an appointed way across the heavens, with the never-ending succession of day and night, and the ever-recurring train of seasons, is one of the subjects of every philosophy. Among all peoples, in all times, there is an explanation of these phenomena, but in the lowest stage, away down in savagery, how few the facts discerned, how vague the discriminations made, how superficial the resemblances by which the phenomena are classified!

In this stage of culture, all the daily and monthly and yearly phenomena, which come as the direct result of the movements of the heavenly bodies, are interpreted as the doings of some one, some good acts. In civilisation, the philosopher presents us the science of astronomy, with all its accumulated facts of magnitude, and weights, and orbits, and distance;, and velocities, with all the nice discriminations of absolute, relative, and apparent motions, and all these facts he is endeavouring to classify in homologic categrories, and the evolutions and revolutions of the heavenly bodies are explained as an orderly succession of events.

\section{(To be continued.)}

\section{UNIVERSITY AND EDUCATIONAL INTELLIGENCE}

CAMBridge.--Exactiy 102 names are in the Cambridge Mathematical Tripos list this year (including three Fgrotant honours). The signification of this is not quite apparent, but lower in the list will be found two whose degree is allowed, but who are not to count it as an honour's degree. These men did well enough in the part of the examination they took to deserve a "poll," and not an honour's degree. Trinity has passed more than a score, St. John's I4, several colleges eight; hut Jesus, Sidney, and Magdalene, as usual, have few mathematicians. Christ $\mathrm{s}$ has picked up well, having no fewer than ten in mathematical honour:; Trinity Hall gets in only two, and Downing has one representative.

Prof. Huinphry announces that his lectures on Anatomy and Phy-iology (the Muscular and Circulatory System:) will be resumed on February 3 , while his classes for the second M.B. and for the Natural sciences Tripos recommence on Friday, February 6. Mr. Wherry (recently elected surgeon to Addenbrooke's Hospital) hegan a class in osteology on January $2 \mathrm{I}$, continuing on Mondays, Wednesdays, and Fridays at I P. M. Dr. Paget's lectures on the Principles and Practice of Fhysic begin on Monday, February 2.

\section{SCIENTIFIC SERIALS}

The Qunrterly Fournal of Microscopical Science, January.H. M. Ward, on the embryo-sac and development of Gymnadenia conopsea, pl. 1-3.-Fred. Elfving, studies on the pollen bodies of the any 10 perms, pl. 4.-F. O. Ruwer, on the development of the conceptacle in the Fucacex, pl. 5.-Dr. Cu.ningham, on certain effects of starvation on vegetable and anımal tissues. J. E. Bluoufield, on the development of spermatızoa; part $\mathbf{I}$, Lumbricus, pl. 6,7-F. M. Balfour, on the spinal nerves of Amphioxus -G. A. Hansen, the bacillus of leprosy, pl. 8.Notes and Memoranda.-Proceed ngs of Dublin Microscopical Club, A pril, 1879, to October, 1879 .

The American Naturalist, vol. xiii. No. 12., December, 1879. -George H. Yerkins, archæology of the Champlain Valley.-
G. de Mortillet, the origin of the domestic animals. - F. Brendel, historical sketch of the science of botany in North America from 1635 to $1840 .-E$. D. Cope, on the extinct American rhinoceroses and their allies.-Recent Literature; General Notes; Scientific News.

Vol. 14, No. 1, January.-Henry J. Rice, observations on the habit:, structure, and development of Amphioxus lanceolatus. - Elliot Cones, sketch of North American ornithology in 1879 -F. Brendel, historical sketch of the science of botany in North America from 1840 to 1858 . - The Editor, notes on the present position of affairs in the Yhiladelphia Academy.-Recent Literature; General Notes; Scientific News.

Procecdings of the Academy of Natural Sciences, Philadelphia, 1879. Part 2, April to October.-Thos. Meehan, on hybrid fuchsias; on special fecurdity in plants; do snakes swallow their young? on Lonas inodora; on sex in Castanea americana; Variations in Thuja and Retinospora.-Rev. H. C. M'Cook, the adoption of an ant-queen; mode of depositing ant-eggs; on the marriage fligh $\mathrm{s}$ of Lasius flavus and Myrmica lobricornis; pairing of Linyphia marginata; on mound-making ants; notes on Tetramorium cespitum; on Myrmecocystus mcxicanus. John A. Ryder : on a new Pauropod and its larva (Eurypauropus spinosus); on a new Chirocephalus, $C$. holnanii; on honey glands on Catalua leaves; description of Streptocephalus sealii, $\mathrm{sp}$. nov.-Dr. Chapman, on Amphiuma; placenta of Macacus cynomolyus.--Dr. Dercum : the lateral sensory apparatus of fishe:- -Dr. Leidy : on rhizopods in Sphagnum; fossil fonttracks of the anthracite coal-measures; explosion of a diamond ; on Orgyia; on some coast animals of New Jersey; on Cris. tatella tda; on Amerba blatte.-E. Potts: on the supposed sensitive ch racters of the glands of the Asclepiadacez.-E. Goldsmith, on amber containing fossil insects.-Angelo Heilprin, on some new eocene fossils from the Claiborne marine formation of Alabama, plate I3.

Revue des Sciences Naturelles, and ser., tome I, No. 3 , December I5, I8j9.-L. Tillier, contributions to a memoir on the geographical distribution of marine fish (conclusion). -A. de Saint-Simon, anatomical notes on some species of Pomatias.$\mathrm{Ph}$. Thomas, note on some species of horses found fossil in the neighbourhood of Constantine.-M. Leymerie, a sketch of the Pyrenees of the department of Aude.-Scientific Review, containing notices of French works on zoology, botany, and geology, published in $1879 .-$ Bulletin.

\section{SOCIETIES AND ACADEMIES LONDON}

Royal Society, November 27, 1879.- “On certain Definite Integrals," No. 6. By W. H. L. Russell, F.R.S.

January 6.-. "On certain Definite Iritegrals," No. 7. By W. H. L. Russell, F.R.S.

"On a Posible Mode of Detecting a Motion of the Solar System through the Luminiferous Ether." By the late Prof. J. Clerk Maxwell. In a letter to Mr. D. P. Todd, Director of the Nantical Almanac Office, Washington, U.S. Communicated by Prof. Stohe, Sec. R.S.

Mr. Todd has been so good as to communicate to me a copy of the subjoined letter, and has kindly permitted me to make any use of it.

As the notice referred to by Maxwell in the Encyclopadic Britannica is very brief, being confined to a single sentence, and as the subject is cne of great interest, I have thought it best to communicate the letter to the Royal Society.

From the researches of $\mathrm{Mr}$. Huggins on the radial component of the relative velocity of our sun and certain stars, the coefficient of the inequality which we might expect as not unlikely, would be only something comparable with half a second of time. This, no doubt, would be a very delicate matter to determine. Still, for anything we know $a$ priori to the contrary, the motior might be very much greater than what would correspond to this ; and the idea has a value of its own, irrespective of the possibility of actnally making the determination.

In his letter to me Mr. Todd remarks, "I regard the communication as one of extraordinary importance, although (as you will notice if you have access to the reply which $I$ made) it is likely to be a lony time before we shall have tables of the satellites of Jupiter sufficiently accurate to put the matter to a practical test," 